\title{
EFFECT OF GENDER ON GROWTH AND CARCASS TRAITS OF ROMNEY MARSH LAMBS
}

\author{
Jan Kuchtík¹, Leona Konečná1 ${ }^{1}$, Monika Šeligová ${ }^{1}$, Tomáš Kopec ${ }^{1}$ \\ ${ }^{1}$ Department of Animal Breeding, Faculty of AgriSciences, Mendel University in Brno, Zemědělská 1, 61300 Brno,
}

Link to this article: https://doi.org/10.11118/actaun202068060959

Received: 11. 9. 2020, Accepted: 3. 11. 2020

To cite this article: KUCHTÍK JAN, KONEČNÁ LEONA, ŠELIGOVÁ MONIKA, KOPEC TOMÁŠ. 2020. Effect of Gender on Growth and Carcass Traits of Romney Marsh Lambs. Acta Universitatis Agriculturae et Silviculturae Mendelianae Brunensis, 68(6): 959-963.

\begin{abstract}
The aim of present study was to assess the effect of the gender on growth and carcass traits in lambs of the Romney Marsh breed. The experimental animals were male lambs $(n=12)$ and female lambs ( $\mathrm{n}=12$ ) of the Romney Marsh breed. All lambs were twins and all their mothers were on the second parity. With regard to body weights and daily gains (DGs), the gender had a significant effect only on birth weight and DG from birth to the slaughter, while in all monitored intervals the DGs were higher in male lambs (MLs). The lamb gender did not have a significant effect on the easy of lambing, body condition score, depth of musculus longissimus lumborum et thoracis (DMLLT) and thickness of backfat (TBF). However, values for DMLLT and TBF were higher in female lambs (FLs), which in case of DMLLT was not expected. Regarding the carcass traits, the gender had a significant effect only on the weights of kidney, kidney fat, leg and shoulder and on the proportions of kidney fat and shoulder. Interestingly, the gender had no significant effect on the conformation and fatness, while slightly better carcass conformation and slightly higher fatness were found in FLs. It can be concluded that FLs of the Romney Marsh breed showed comparable values for both the growth and carcass traits with MLs. Moreover, a slightly higher fatness of FLs is a prerequisite for better juiciness and tenderness of their meat, when this fact can be considered as a benefit in the marketing.
\end{abstract}

Keywords: lamb, gender, growth, carcass, easy of lambing, ultrasound measurements

\section{INTRODUCTION}

Many publications show that nutrition, health, breed and management are key factors, that affect the growth and carcass traits of lambs. However, a relatively important factor that also affects both growth and carcass traits of lambs is their gender. Many experiments show that male lambs (MLs) have more intensive growth rate compared to female lambs (FLs), but Jaborek et al. (2017) reported comparable growth intensity in FLs and wether lambs and Simeonov et al. (2014) found more intense growth in FLs during suckling period. With regard to carcass traits, in FLs is often recorded the higher dressing percentage (DP) and fatness compared to MLs (Cividini et al., 2005; Rodríguez et al., 2008). However, Kuchtík et al. (2011) found only slightly higher DP in MLs.

In the Czech Republic about 90 to 95\% of MLs is slaughtered and the rest of MLs (5-10\%) is used in breeding. In contrast, 25 to 50\% of FLs is used for breeding as replacement for culled ewes and 50 to $75 \%$ of them is slaughtered. Thus, it follows from the above mentioned fact that the number of slaughtered FLs on the domestic market is lower than the number of slaughtered MLs, however, its number is still quite high. In this context, it is also necessary to state that most of experiments focused on growth and carcass traits of lambs were performed in MLs, while the number of similar experimental evaluations in FLs has been sporadic so far. For this reason, the main goal of 
our experiment was to evaluate the effect of the gender on growth and carcass traits in lambs of the Romney Marsh breed, when this breed, for its resistance is suitable for sheep meat production in harsher climatic conditions.

\section{MATERIALS AND METHODS}

The experiment was carried out on the organic farm in the Zlín region in the Czech Republic. The altitude of this farm ranges from 250 to 700 meters above sea level. The average annual precipitation and temperature are $780 \mathrm{~mm}$ and $6.8^{\circ} \mathrm{C}$, respectively. The experimental animals were male lambs (MLs, $n=12$ ) and female lambs (FLs, $n=12$ ) of the Romney Marsh breed. All lambs were twins and their mothers were on the second parity. All lambs were born during April, on the pasture. Throughout the experiment, the lambs were reared together with their mothers and the weaning of lambs was carried out just before slaughter. Throughout the experiment the daily feeding ration of the lambs consisted of mother's milk (ad libitum), pasture (ad libitum) and organic mineral lick (ad libitum). All animals had free and uninterrupted access to drinking water. During the experiment, all of the lambs were reared in one flock under identical conditions without any discernible differences in nutrition or management.

All lambs were weighed at birth (LWO). On the day of birth easy of lambing (EL) was also assessed. The EL was assessed by the same person using a 4-point scale ( $1=$ no assistance, 2 = some assistance, 3 = hard assistance and $4=$ veterinary assistance). The measurements of live weight at 100 days (LW100), body condition score (BCS), depth of musculus longissimus lumborum et thoracis (DMLLT, in $\mathrm{mm}$ ) and thickness of backfat (TBF, in $\mathrm{mm}$ ) were performed in vivo at 100 days post partum (recalculated by linear interpolation). The evaluation of BCS was carried out by the same person according to Russel et al. (1969), on a 1-5 scale (BCS 1 = emaciaded, BCS 5 = obese). The ultrasound measurements (UMs) of DMLLT and TBF were carried out by the same person according to Hošek et al. (2008).

At the end of the experiment, after 24 hours of starvation, lambs were slaughtered. On the day of slaughter, live weights of lambs (LWS) and age of lambs were recorded. The lambs of both genders were slaughtered at a similar range of age and at similar average age, while the average age at slaughter was in MLs 121 days and in FLs 123 days. The slaughters of both lamb genders were carried out according to EU laws and the procedures were conducted according to the guidelines of the Council Directive 86/609/EEC on the protection of animals used for experimental and other scientific purposes. On the following day, after a chilling period of approximately $24 \mathrm{~h}$. a subjective carcass evaluation of the conformation and fatness according to
S.E.U.R.O.P. evaluation system was performed. The conformation score (an extent of the scale from $\mathrm{S}=$ exceptional to $\mathrm{P}=$ poor conformation) and fatness score (the scale from 1 = very low fatness to 5 = very high fatness) were assessed according to the S.E.U.R.O.P. evaluation system (Commission Regulation EEC 461/93). For the purpose of statistical analysis, the scale of the conformation score was quantified from the grade $S=6$ to the grade $\mathrm{P}=1$. The evaluation of conformation and fatness was carried out by the same person.

Subsequently, the weights od carcass, kidney, kidney fat, skin with wool, leg and shoulder were recorded. The weighing of carcass, kidney, kidney fat, skin with wool, leg and shoulder was carried out using a digital scale with an accuracy of $\pm 0.01 \mathrm{~kg}$. After weighing, the dressing percentage and the proportions of kidney, kidney fat, skin with wool, leg and shoulder were calculated. Weighing of all lambs at birth, at 100 days of age and at slaughter was carried out using a digital scale with an accuracy of $\pm 0.1 \mathrm{~kg}$. Daily gains (DGs) were calculated in grams (g) in the intervals from LWO to LW100 and from LW0 to LWS.

Recorded traits were statistically analysed. The dataset was analysed by statistical program SAS 9.1. The effect of the gender on the carcas traits was tested by the analysis of variance procedure PROC ANOVA (post hoc analysis using Scheffe test) and correlation coefficients was estimated using procedure PROC CORR. Statistical significance was tested at level of significance $\alpha=0.05$ (marked ${ }^{*}$ ), resp. $\alpha=0.01$ (marked ${ }^{* *}$ ).

\section{RESULTS AND DISCUSSION}

As expected, the daily gains (DGs) from birth to 100 days of age and from birth to the slaughter were in both cases higher in male lambs (Tab. I). This fact subsequently reflected in their higher live weight both at 100 days of age (LW100) and at slaughter (LWS). However, the DG from birth to 100 days of age and LW100 were only slightly higher in male lambs (MLs) as compared to FLs. In contrast, the DG from birth to the slaughter and LWS were markedly $(\mathrm{P}<0.05)$ higher in MLs than in FLs, which is in line with findings of Rosa et al. (2007) and Facciolongo et al. (2018). Besides that, the average age at slaughter was comparable in both genderes (121 and 123 days in MLs and FLs, resp.). One of the most important factors that affects the growth of lambs after birth is easy of lambing (EL). Brown (2007) states that EL is positively genetically correlated with the birth, weaning and post weaning weight. Jacobson et al. (2020) add that, one of the most important factor which affects the EL is a birth weight. According to McHugh et al. (2016), lambing difficulties are also affected by the parity when the most threatened females are primiparous ewes. However, in the present study, all ewes were on the second parity. 
I: Effect of gender on easy of lambing, growth, BCS, DMLLT and TBF

\begin{tabular}{|c|c|c|c|}
\hline \multirow{2}{*}{ Trait } & \multicolumn{2}{|c|}{ Gender } & \multirow{2}{*}{ Significance } \\
\hline & Males & Females & \\
\hline Easy of lambing & 1.83 & 1.67 & n.s. \\
\hline Birth weight (kg) & 5.13 & 4.68 & $*$ \\
\hline Live weight at 100 days $(\mathrm{kg})$ & 31.40 & 29.88 & n.s. \\
\hline Daily gain from birth to 100 days (g) & 263 & 252 & n.s. \\
\hline Age at slaughter (days) & 121 & 123 & n.s. \\
\hline Live weight at slaughter (kg) & 38.84 & 34.58 & $*$ \\
\hline Daily gain from birth to slaughter (g) & 279 & 243 & $*$ \\
\hline Body condition score ${ }^{1}$ & 3.67 & 3.67 & n.s. \\
\hline Depth of MLLT (mm) ${ }^{2}$ & 24.58 & 25.17 & n.s. \\
\hline Thickness of backfat (mm) & 3.33 & 4.00 & n.s. \\
\hline
\end{tabular}

${ }^{1}$ Body condition score (BCS) is based on a 1-5 scale (BCS $1=$ emaciaded, BCS $5=$ obese)

${ }^{2}$ MLLT $=$ musculus longissimus lumborum et thoracis, n.s. - not significant, ${ }^{*} \mathrm{P}<0.05$

II: Effect of gender on carcass traits

\begin{tabular}{|c|c|c|c|}
\hline \multirow{2}{*}{ Trait } & \multicolumn{2}{|c|}{ Gender } & \multirow{2}{*}{ Significance } \\
\hline & Males & Females & \\
\hline Weight of carcass (kg) & 16.58 & 14.63 & $*$ \\
\hline Dressing percentage(\%) & 42.67 & 42.28 & n.s. \\
\hline Kidney (kg) & 0.12 & 0.10 & $*$ \\
\hline Kidney (\%) & 0.75 & 0.72 & n.s. \\
\hline Kidney fat (kg) & 0.19 & 0.24 & $*$ \\
\hline Kidney fat (\%) & 1.15 & 1.66 & $*$ \\
\hline Skin with wool (kg) & 3.48 & 3.24 & n.s. \\
\hline Skin with wool (\%) & 8.98 & 9.36 & n.s. \\
\hline Leg (kg) & 5.42 & 4.72 & $*$ \\
\hline Leg (\%) & 32.69 & 32.27 & n.s. \\
\hline Shoulder (kg) & 2.96 & 2.48 & $*$ \\
\hline Shoulder (\%) & 17.85 & 16.95 & $*$ \\
\hline Conformation $^{1}$ & 3.67 & 3.58 & n.s. \\
\hline Fatness $^{2}$ & 2.83 & 3.17 & n.s. \\
\hline
\end{tabular}

${ }^{1}$ Conformation score is based on a numeric scale from the grade $\mathrm{S}=6$ to the grade $\mathrm{P}=1$

${ }^{2}$ Fatness score is based on a numeric scale from 1 = very low fatness to 5 = very high fatness, n.s. - not significant, ${ }^{*} \mathrm{P}<0.05$

In the present study, the course of parturition was insignificantly easier in FLs than in MLs, which is in line with Brown (2007). In addition, FLs of the present study had also the lower BW0 compared to MLs which is consistent with the finding of Taskin et al. (2012). In contrast, Hošek et al. (2008) found the higher BW0 in FLs. It is interesting, that EL in FLs of the present study, compared to MLs, was positively correlated $(\mathrm{P}<0.05)$ with $\mathrm{DGs}$ from birth to 100 days of age and from birth to the slaughter. In contrast to MLs, FLs of the present study also showed a positive correlation $(\mathrm{P}<0.05)$ between
BW0 and DG from birth to 100 days of age. In addition, regarding growth intensity of lambs in the present study, the DGs in both lamb genders, despite their relatively extensive nutrition, were markedly higher than those found by Rosa et al. (2007) in the Romney Marsh lambs and by Kuchtík et al. (2010) in lambs of meat type breeds.

The gender had no effect on body condition score, when the average values of this parameter were the same for both genders. However, both genders of the present study were more obese than reported Ptáček et al. (2018) in lambs of the Wallachian 
sheep. The gender also had no significant effect on depth of musculus longissimus lumborum et thoracis (DMLLT) and thickness of backfat (TBF), while slightly higher values of these traits were found in FLs. In case of TBF, this fact was expected and it is in accordance with the data published by Janoš et al. (2018). Nevertheless, in both of the above mentioned studies the MLLTs were deeper in MLs compared to FLs.

Regarding the carcass traits (Tab. II), the gender did not have significant effect on dressing percentage (DP), while its slightly higher value was found in MLs, which is in accordance with Kuchtík et al. (2011). In contrast, Rosa et al. (2007) found in both genders of the Romney Marsh lambs a higher DP compared to findings of the present study. Also Mioč et al. (2013) found significantly higher DP in both genders of the Dalmatian Pramenka lambs than in the present study. One of the key factors that affects the DP is the weight, respectively the proportion of skin with wool. In the present study, the weights and proportions of skin with wool were comparable in both genders, but both these proportions were lower than those found by Sabbioni et al. (2016). However, the gender of the present study had a significant effect on kidney weight, when its higher weight was found in MLs. In contrast, Kaič et al. (2016) reported the slightly higher weight of kidney in FLs. Regarding the weight and proportion of kidney fat, their higher values were found in FLs, which is in case of weight consistent with Jaborek et al. (2017) and in case of its proportion, our finding is consistent with Kaič et al. (2016). With the exception of the leg proportion, the weights and proportions of leg and shoulder were significantly higher in MLs compared to FLs, which is in accordance with Kaič et al. (2016). In contrast, Sabbioni et al. (2016) reported in FLs slaughtered at 6 to 12 months of age the higher proportions of shoulder and leg, while Rosa et al. (2007) found higher proportions of the leg in the FLs of Romney March breed. However, the differences between the proportions of shoulder and leg found in the present study and the proportions of these cuts in the above mentioned studies were very small $(2-3 \%)$. The higher TBF and the proportion of kidney fat in FLs of the present study indicated that the fatness would also be higher in this gender, which was subsequently confirmed. However, the fatness was only slightly higher in FLs than in MLs, which is in line with Simeonov et al. (2014) and Facciolongo et al. (2018). Many studies have showed that carcass conformation is better in MLs compared to FLs. In contrast, in the present study, slightly better conformation was found in FLs, which is consistent with Cividini et al. (2005), whereas Žgur et al. (2003) found the same carcass conformation in both genders. In conclusion, it should also be noted in general, that lambs of the Romney March are comparable in their growth intensity and level of most carcass traits to specialized meat breeds.

\section{CONCLUSION}

The results of the present study show that female lambs, despite relatively extensive nutrition, had relatively high daily gains in all monitored intervals. However, female lambs had all daily gains assessed lower than male lambs. Course of parturition was slighty easier in female lambs, and this lamb gender displayed comparable body condition score and values of ultrasound measurements with male lambs. Both lamb genders had comparable dressing percentages and proportions of leg, whereas female lambs displayed unexpectedly slightly better carcass conformation. Female lambs showed also slightly deeper MLLT. On the other hand, in this gender a slightly higher thickness of backfat was found. In conclusion, it can be stated that despite relatively low number of monitored lambs, female lambs of the Romney Marsh breed showed comparable values for both the growth and carcass traits with male lambs. Moreover, a slightly higher fatness of female lambs is a prerequisite for better juiciness and tenderness of their meat, when this fact can be considered as a benefit in the marketing.

\section{REFERENCES}

BROWN, D. J. 2007. Variance components for lambing ease and gestation lenght in sheep. Proc. Assoc. Advmt. Anim. Breed. Genet., 17: 268-271.

CIVIDINI, A., ŽGUR, S. and KOMPAN, D. 2005. The crossbreeding of improved Jezersko-Solčava sheep with Charollais to improve carcass traits. Italian Journal of Animal Sci., 4(3): 163-165.

EUROPEAN COMMISSION. 1993. Commission Regulation (EEC) No. 461/93 of 26 February 1993 laying down detailed rules for the Community scale for the classification of carcases of ovine animals. Brussels: European Commission.

FACCIOLONGO, A. M., LESTINGI, A., COLONNA, M. A., NICASTRO, F., DE MARZO, D. and TOTEDA, F. 2018. Effect of diet lipid source (linseed vs. soyabean) and gender on performance, meat quality and intramuscular fatty acid composition in fattening lambs. Small Ruminant Research, 159: 11-17. 
HOŠEK, M., KONEČNÁ, L., KUCHTÍK, J. and FILIPČÍK, R. 2008. Effect of breed, sex and litter size on growth and meatiness and fattiness in vivo in lambs. Acta Universitatis Agriculturae et Silviculturae Mendelianae Brunensis, 56(4): 231-237.

JABOREK, J. R., ZERBY, H. N., MOELLER, S. J. and FLUHARTY, F. L. 2017. Effect of energy source and level, and sex on growth, performance, and carcass characteristics of lambs. Small Ruminant Research, 151: 117-123.

JACOBSON, C., BRUCE, M., KENYON, P. R., LOCKWOOD, A., MILLER, D., REFSHAUGE, G. and MASTERS, D. G. 2020. A review of dystocia in sheep. Small Ruminant Research, 192: 1-6.

JANOŚ, T., FILIPČÍK, R. and HOŠEK, M. 2018. Evaluation of growth intensity in Suffolk and Charollais sheep. Acta Universitatis Agriculturae et Silviculturae Mendelianae Brunensis, 66(1): 61-67.

KAIČ, A., MIOČ, B., ŠIRIČ, I. and DRŽAIČ, V. 2016. Influence of sex and the slaughtering season on water-holding capacity and carcass composition in Istrian lambs. Veterinarski Arhiv., 86(1): 111-123.

KUCHTÍK, J., DOBEŠ, I. and HEGEDÜŠOVÁ, Z. 2010. Growth of lambs of crossbreeds of Romanov, Suffolk and Charollais breeds - effect of sex, litter size and season. Acta Universitatis Agriculturae et Silviculturae Mendelianae Brunensis, 58(5): 233-238.

KUCHTÍK, J., DOBEŠ, I. and HEGEDÜŠOVÁ, Z. 2011. Effect of genotype, sex and litter size on growth and basic traits of carcass quality of light lambs. Acta Universitatis Agriculturae et Silviculturae Mendelianae Brunensis, 59(3): 111-116.

MCHUGH, N., BERRY, D. and PABIOU, T. 2016. Risk factors associated with lambing traits. Animal, 10(1): 89-95.

MIOČ, B., DRŽAÍĆ, V., VNUČEC, I., PRPIĆ, Z., ANTUNOVIĆ, Z. and BARAĆ, Z. 2013. Some slaughter and meat traits of lambs and kids from an extensive production system. Veterinarski Arhiv, 83(3): 263-274.

PTÁČEK, M., MILERSKI, M., SCHMIDOVÁ, J., DUCHÁČEK, J., TANČÍN, V., UHRINČÁT, M., HAKL, J. and STÁDNÍK, L. 2018. Relationship between body mass index, body energy reserves, milk, and meat production of original Walachian sheep. Small Ruminant Research, 165: 131-133.

RODRÍGUEZ, A. B., BODAS, R., PRIETO, N., LANDA, R., MANTECÓN, A. R. and GIRÁLDEZ, F. J. 2008. Effect of sex and feeding system on feed intake, growth, and meat and carcass characteristics of fattening Assaf lambs. Livestock Science, 116(1-3): 118-125.

ROSA, H. J. D., VENTURA, P. F. M., SOUSA, J. T., MOREIRA, D., BORBA, A. E. S. and REGO, O. A. 2007. Productive and reproductive performance of Romney Marsh and Merino Branco sheep in the Azores under different feeding regimens. Small Ruminant Research, 67(2-3): 296-301.

RUSSEL, A. J., DONEY. F. J. M. and GUNN, R. G. 1969. Subjective assessment of fat in live sheep. Journal of Agriculture Science, 72: 451-454.

SABBIONI, A., BERETTI, V., ZAMBIANI, E. M. and SUPERCHI, P. 2016. Carcass and meat parameters in Corniglese sheep breed as affected by sex and age-class. Italian Journal of Animal Science, 15(1): 2-9.

SIMEONOV, M., TODOROV, N., NEDELKOV, K., KIRILOV, A. and HARMON, D. L. 2014. Influence of live weight, sex and type of birth on growth and slaughter characteristics in early weaned lambs. Small Ruminant Research, 121(2-3): 188-192.

TASKIN, T., KAYMAKCI, M., SÖNMEZ, R., YILMAZ, M. and BARDAKCIOGLU, H. E. 2012. Genetic and non-genetic parameter estimates for growth traits of Sönmez lambs. Veterinaria ir zootechnika (Vet Med Zoot), 60(82): 79-83.

ŽGUR, S., CIVIDINI, A., KOMPAN, D. and BIRTIČ, D. 2003. The effect of live weight at slaughter and sex on lambs carcass traits and meat characteristics. Agriculturae Conspectus Scientificus, 68(3): 155-159.

Contact information

Tomáš Kopec: tomas.kopec@mendelu.cz 